\title{
Struggles and Coping Strategies of Student Mothers at the University of Cape Coast Distance Education, Ghana
}

\author{
Joyce Kwakyewaa Dankyi, Lydia Aframea Dankyi, Vincent Mensah Minadzi \\ College of Distance Education, University of Cape Coast, Cape Coast, Ghana \\ Email: joyce.dankyi@ucc.edu.gh, lydia.dankyi@ucc.edu.gh,vincent.minadzi@ucc.edu.gh
}

How to cite this paper: Dankyi, J. K., Dankyi, L. A., \& Minadzi, V. M. (2019). Struggles and Coping Strategies of Student Mothers at the University of Cape Coast Distance Education, Ghana. Creative Education, 10, 2484-2494.

https://doi.org/10.4236/ce.2019.1011176

Received: October 6, 2019

Accepted: November 18, 2019

Published: November 21, 2019

Copyright ( 2019 by author(s) and Scientific Research Publishing Inc. This work is licensed under the Creative Commons Attribution International License (CC BY 4.0).

http://creativecommons.org/licenses/by/4.0/

\begin{abstract}
We investigated into combining motherhood with academic life concentrating on the struggles of student-mothers. The study adopted the mixed method design affirming the qualitative data with quantitative data. The purposive and convenient sampling procedures were used to select the sample from the University of Cape Coast Distance Education, Oyoko Study Center. The study found that majority of respondents go through academic struggles such as inability to attend face-to-face lectures regularly because of tiredness, sickness of child, taking baby to child welfare clinic and lack of lactating rooms for breastfeeding of babies. To cope with the struggles respondents relied on paid house helps, keeping children at day care centers, raising loans and relying on husbands and friends for support. The study recommended for the provision of lactating rooms, day care centers and counselling services for student-mothers on all centers of the College of Distance Education.
\end{abstract}

\section{Keywords}

Student-Mothers, Coping Strategies, Struggles, Face-to-Face, Distance Education

\section{Introduction}

Education is believed to provide knowledge and skills that hold potentials for economic empowerment, for better livelihood and social development. Jekayinfa (2009) postulated that the educational system of any society is an elaborate social mechanism designed to bring about in a person certain skills and attitudes that are adjudged to be useful and desirable in the society.

According to Obioma and Ngozichukwuka, cited in Adofo (2013), as a result 
of the necessity for education, there has been the view that one who ceases to learn ceases to exist although the one may be living.

However, in the traditional society, it is perceived that the man is the head of the family and breadwinner and so needs to be educated for better employment and higher income. The woman who is the heart and keeper of the home must be trained at the kitchen (Mumuni, 2000). Marriage and housekeeping also limit the role of women (Asiedu-Akrofi, 1978; Edwards, Hasebe, \& Sakai, 2019).

Moreover, the recent trend in the world economy has made it necessary for women to act as co-breadwinners of the family and therefore must be educated to gain employment so as to earn a living (Dolphyne, 1991; Hossain, Niaz Asadullah, \& Kambhampati, 2019). The trend has made it necessary for women of today to be educated so that they will be equipped with the skills, knowledge and attitudes required to fit into the ever-growing global economy.

Hence, a lot of educational reforms have been embarked upon, targeting both male and female participation at all levels of education in Ghana (Adusah-Karikari, 2008). This has led to a dramatic increase in the numbers of tertiary institutions at both regular and distance levels.

Dankyi and Dankyi, (2015), also stressed on the need for females to take advantage of UCC Distance Education Programme, which is an appreciable improvement in flexible mode of education.

Nevertheless, Caplan (1993), notes that the academic tenure clock and women's biological clocks coincide. Due to their reproductive responsibilities women have had to combine their quest for higher education with child birth. This has resulted in a phenomenon of student mothers in our various higher educational institutions.

This phenomenon has brought in its wake a lot of struggles by the student mothers considering the fact that the universities do not have facilities like lactation rooms, and convenient places for the baby sitters who accompany them while the home setting may pose other challenges that prevent the student mother from leaving the child at home. According to Egenti and Omoruyi (2011) the stress and trauma which they have to go through make them feel psychologically, emotionally and physically ill-disposed towards the programme.

The effect of the inadequate support systems in the universities and the home in terms of academics, child care and financial support cannot be overemphasized. This study thus seeks to find out the struggles in terms of academics, child care, financial issues and coping strategies of student mothers who combine the worlds of family and academic pursuits by the distance education mode at the University of Cape Coast.

\section{Justification and Novelty}

Many empirical studies have been conducted in this area however the focus is on the general challenges that students face in the various regular university (Eyster, Callan, \& Adams, 2014; Beeler, 2016). Few of these studies focused on student 
mothers in regular universities (Bruening, Argo, Payne-Sturges, \& Laska, 2017). However fewer studies have looked into challenges of distance education students and worsened in numbers among student mothers in distance education mothers in Africa. Our study therefore is among few if any studies that target the student-mothers in the distance education program. Further statistically females form a higher percentage of students in the distance education program (Nelson, Froehner, \& Gault, 2013). A study to investigate the specific needs of the higher proportion of distance education program in Ghana, female students, will go a long way to better the Program.

\section{Theoretical Framework}

\subsection{The Role Conflict Theory Was Used to Underpin the Study}

According to Wolf as cited in Adofo (2013), the term role conflict refers to a clash between two or more of a person's roles or incompatible features within the same role. These incompatibilities can consist of differing expectations, requirements, beliefs, and/or attitudes. Wolf (in Adofo, 2013) identified two types of role conflict: intra-role conflict, referring to incompatible requirements within the same role, and inter-role conflict, referring to clashing expectations from separate roles within the same person. Intra-role conflict can arise in two ways. First, different people sometimes have inconsistent conceptions concerning the requirements and expectations that constitute a particular role.

Inter-role conflict arises when the requirements and expectations of one role interfere or conflict with those of another role. Glady's role as mother is likely to conflict occasionally with her role as a student, as an example.

According to Parson (1971) for society to function very well, it has social institutions in which we have roles and statuses. Every status is attached with a role, which the status incumbent is expected to perform without waver. He used the idea of shared expectation based on the status one occupies in society.

\subsection{Consequences of Role Conflict}

Research finds role conflict to be associated with both positive and negative consequences. Much attention had been given to the problems associated with multiple roles. Role overload and role conflict are two of the most well-known role theory concepts. Role overload refers to the experience of lacking the resources, including time and energy, needed to meet the demands of all roles. Role overload and conflict often lead to difficulties with meeting role expectations, known as role strain (Goode, 1960; Liu, Wang, Min, \& Li, 2019).

According to Egenti and Omoruyi (2011) the stress and trauma which student mothers go through makes them feel psychologically, emotionally and physically ill-disposed towards the programme. This has led to some dropping out of the programme. In addition, some have to contend with pregnancy while others nurse their new born babies alongside their studies. This further increases their burden and has made some to fail their exams while some have had to even ab- 
andon their examinations. Some come late for lectures because of their marital demands or even stay away from lectures for a reasonable period as a result of home pressure and demands. All these affect their learning and level of achievement (Egenti \& Omoruyi, 2011).

Smith, (2019) on the other hand, in a study found that both pregnant and nursing students had their studies negatively affected by financial problems. When financial resources were not sufficient to sustain them, students temporarily absconded from some educational activities such as lectures to source funds and or other essential materials.

Furthermore, Najjuma and Kyarugah (2006) established in their research that student mothers go through a lot of struggles by their triple roles, i.e. productive, reproductive and community service, which is likely to bring stress, anxiety, and some time, may lead to diseases. Therefore they recommended that, support services such as counseling must be provided to student mothers in order to manage better the struggles brought about by the challenges they face.

\subsection{Coping Behaviour for Dealing with Inter-Role Conflict}

Hall, as cited by, Adofo (2013) has identified three types of coping behaviour for dealing with inter-role conflict.

Type I coping (structural role redefinition) involves an active attempt to deal directly with role senders and lessen the conflict by mutual agreement on a new set of expectations. One way of changing structural demands would be to relocate and share one's role tasks (cleaning, washing, and child care, for example).

Type II coping (personal role redefinition) involves changing one's personal concept of role demands received from others. It entails changing the expectations themselves.

Type III coping (reactive role behaviour) entails attempting to improve the quality of role performance with no attempt to change the structural or personal definition of one's roles.

Najjuma and Kyarugah (2006) on the other hand found out that some women either take their children with them, use paid domestic workers, leave children with neighbours, relatives, older siblings, or take them to day care centres. One coping strategy that cannot be ignored is the support from the family, especially, husbands, grandparents and other relatives. Writing on coping strategies used by student mothers to succeed in Occupational Therapy School which revealed that physical support from husbands was used by all the participants. Emotional support from husband and peers and time management strategies was used by $93.3 \%$ of the participants. Findings concluded that $100 \%$ of the participants who had their first child in school reported that they used emotional and physical support from their husband and parents and time management strategies.

Finally, despite all the challenges Smulyan, (2004) postulates that student moth- 
ers may attempt to redefine their own roles as mothers, or their expectations of themselves as students or they may try to re-negotiate the support they receive from family and friends. They may even redefine how they see the university system, and their role within it. A student mother may try any or all of these strategies at one time or another.

\section{Context}

The student mothers at Oyoko study center may go through a lot of struggles as a result of the inter and intra-role conflict they experience in their attempt to combine education, childcare and other social responsibilities. Societies may have their own expectations based on the different roles they assume. Student mothers would have to adopt coping strategies such as; Changing the structural demands by sharing roles, Changing their own expectations about their roles, and working very hard to meet all standards concerning their roles.

\subsection{Approach}

The study adopted the mixed method research design, specifically the concurrent mixed methods design was used. According to Creswell (2014) the mixed methods research is a research design with philosophical assumptions as well as methods of inquiry. It focuses on collecting, analyzing, and mixing both quantitative and qualitative data in a single study or series of studies. Its central premise is that the use of quantitative and qualitative approaches in combination provides a better understanding of research problems than either approach alone (Creswell, 2014).

\subsection{Population}

The target population for the study consists of all student mothers of the College of Distance Education of the University of Cape Coast, Oyoko study centre. In all, they were 51 in number.

The purposive and convenient sampling techniques were used to select all the 51 student mothers.

The choice of student mothers is based on the reason that, according to a research by Erickson (1982), children under the age of five years need more attention from their mothers especially to grow and develop well psychosocially. A semi-structured questionnaire was used to collect data from 41 of the mothers, whereas 10 were interviewed using an interview guide.

\subsection{Data Analysis}

Firstly, the data which emanated from the closed ended questions were edited, coded and analyzed using the Statistical Package for Social Sciences (SPSS) version 17 and Excel. The results were then presented descriptively in frequencies and percentages using tables. Secondly, descriptive-narrative method was used to analyze the qualitative responses generated through the open ended questions. The 
data were transcribed, coded and analyzed manually, and presented narratively.

\section{Results and Findings}

\subsection{Struggles with Face-to-Face Attendance}

The uniqueness of the distance learner considering the general characteristics of Distance Education informed researchers to probe into the struggles that student mothers encounter with attending face to face, a student support system that aim at helping students to understand the models. Figure 1 represents the respondents view on the struggles. From Figure 1, key among the factors that the student-mothers pointed at was tiredness $(85.4 \%)$ and attending to baby (75.6\%). Least but also worth mentioning in the rating of the respondents was solving personal problems (34.1\%).

The qualitative data also supported the results. A young student mother said:

"Sometimes the whole week is so packed that I hardly get the time to rest, so I cut some lectures in order to see to that. It even becomes worst when the child is sick and is unwilling to go to any other person, the stress is too much". The finding is in line with Egenti and Omoruyi (2011) who posited that, the stress and trauma which student mothers go through makes them feel psychologically, emotionally and physically ill-disposed towards the programme. This has led to some dropping out of the programme.

\subsection{Struggles with Learning}

Table 1 represents responses of respondents on struggles that hinders their

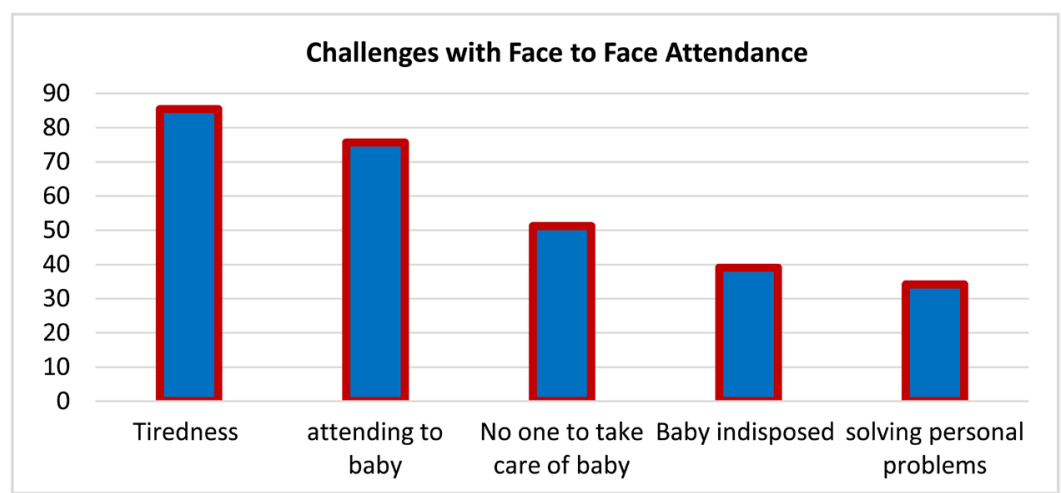

Source: Field data 2019.

Figure 1. Struggles with face to face attendance.

Table 1. Struggles with learning.

\begin{tabular}{ccc}
\hline Struggles with learning & No. & $\%$ \\
\hline Lack of concentration & 39 & 75.6 \\
Combining childcare and night learning & 31 & 61 \\
Difficulty in understanding topics taught in my absence & 23 & 41.5 \\
Inability to access library facilities & 5 & 9.8 \\
\hline
\end{tabular}


learning. The responses revealed that the main difficulty confronting the respondents in their learning was lack of concentration (75.6\%) with the least difficulty being inability to access libraries facilities. The result shows that most of the difficulties that respondents faced were related to learning at home and either caring for the child or performing house chores.

This is exemplified in the following comments made by two respondents during the interview.

"Hmm! Learning is the most difficult aspect of the course. By the time I am done with caring for the baby and other kids I get so tired that I end up dozing off when I sit behind the books. My only luck is the occasional support I get from my husband" "Eh! When you have an uncooperative husband as I have and who is of the opinion that I am too ambitious, you have no alternative but to find a way of facing all the odds and as well as find time to learn". This is also consistent with Goode (1960) who stated that role overload may lead to experience of lack of resources such as time and energy needed to meet the demands of all roles.

\subsection{Struggles with Examination}

All the respondents, (100.0\%) found it difficult to prepare adequately for examination, 87.8 percent found it difficult to get a place to keep their babies during exams, in addition, divided attention, and the inability to breastfeed the babies during exams were the most challenges faced by the respondents respectively, while the least challenge faced by respondents was fatigue and stress during examinations, 12.2 percent. During the interview a respondent recounted her experience as:

"I recount the experience when my baby sitter sat under a tree some few meters away from the exam room when in the course of the exam I heard my baby cry out very loudly. In fact, it was the worst experience I ever had. In a confused state I sought permission from the invigilator who reluctantly allowed me under the watch of an assistant invigilator to go and check what was happening to the child. It really took me some time to resettle when I returned to write the exams".

Similar to the experience above was the comment made by another respondent as follows:

"I always become fearful when it is nearing exams. This is because I am unable to learn effectively and my domestic responsibilities will as well not allow me to concentrate and learn. My daily prayer during exam is that my daughter will not fall sick, in fact that will be disaster for me". This is also in agreement with Adofo (2013) who was of the view that, the role conflict experience by nursing mothers leads to clashing expectations from separate roles.

\subsection{Struggles with Support for Childcare}

Figure 2 represents the views of the respondents on struggles with support for child care. The results indicated that, the major challenges faced by respondents 


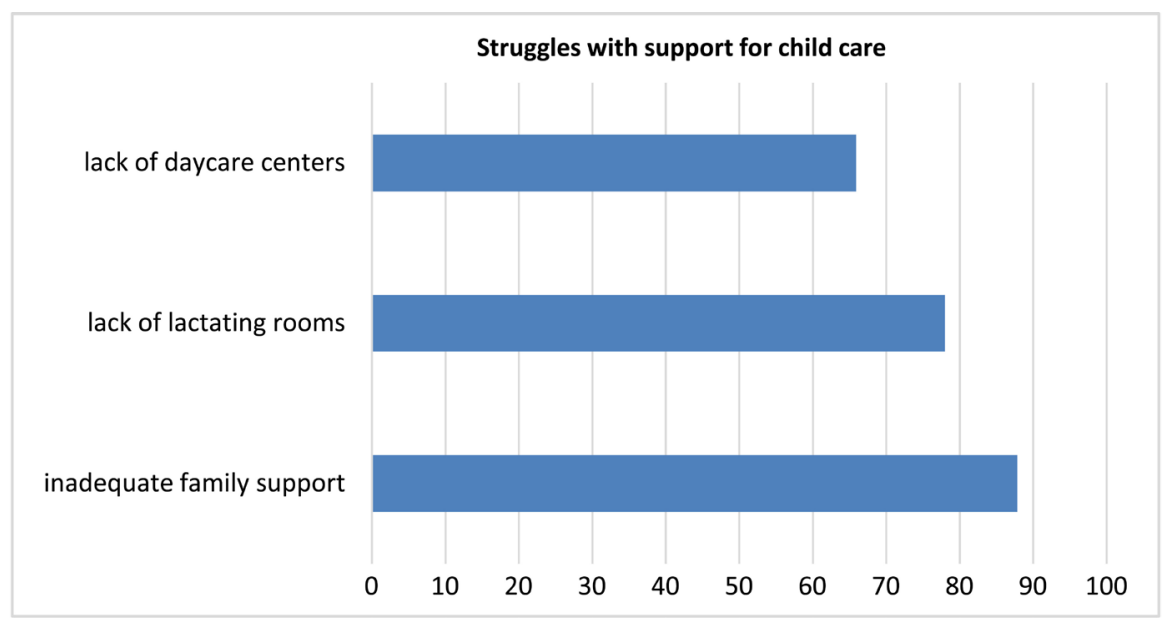

Figure 2. Struggles with support for childcare.

as they combine academic work with childcare are inadequate family supports (87.8\%), lack of lactating rooms (78.0\%), and lack of daycare centres to keep the babies safe (65.9\%).

Lamenting on the effect of academic work on child care a respondent said:

"My main problem is leaving my child in the care of another person whose care for the baby may not be adequate. I sometimes feel that I am shirking my responsibility. Really, it is a difficult situation".

Commenting on inadequate family supports, a respondent said:

"My only luck is the level of support I receive from my husband. Apart from paying part of my fees, he daily gives us lift, helps me in my assignments and takes the kids to school. In any case he encouraged me to enroll so he sees it as a responsibility to assist me".

The view expressed above represents an ideal condition that few respondents enjoy. A contrary view expressed concerning inadequate family supports is as follows:

What makes my burden heavier as a student nursing mother is the attitude of my husband. Though he initially accepted my enrolment he has become so apathetic. He insists that I am chasing my degree at the expense of the child s welfare and at the neglect of the family at large. Because of this he easily picks up quarrels with me on very trivial matters. I sometimes feel like abandoning the programme. I pray that he changes". This finding corroborate with that of Najjuma and Kyarugah (2006) who established that, student mothers are challenged by the triple role of productive, reproductive and community service, which is likely to bring stress, anxiety and sometimes diseases, and therefore must be provided with support services such as counseling in order to manage the struggles they go through.

\subsection{Financial Struggles}

Results showed that payment of fees was the major financial struggle, 78.0 percent. Cost of employing the services of a baby sitter was stated as a challenge by 
65.9 percent of respondents. This was followed by money for transportation expenses as a financial challenge by 51.2 percent, then hostel accommodation fees challenge was stated by 36.6 percent of respondents. Buying weaning food for the baby as a financial challenge was stated by 24.4 percent of the respondents, and the last but not the least financial challenge was photocopies of learning materials by 19.5 percent of respondents. This finding also agrees with that of Mamhute (2011) who found out that both pregnant and nursing students had their studies negatively affected by financial problems, when financial resources were not sufficient to sustain them.

\subsection{Coping Strategies Adopted by Student Mothers}

In order to cope with the conflicting roles of motherhood and hectic academic demands, student mothers on preparation for examination, 51.2 percent of them engaged in group studies, 24.4 percent studied at night when the baby is asleep, 17.1 percent relied on husband and other relatives to help take care of the babies, while the least 14.6 percent organize special classes with course tutors when they do not understand what they learnt.

Commenting further on the coping strategy a respondent said: "My biggest thanks go to my mother who comes to stay with us during the examination week. She is a big relief". Respondents were further asked to indicate how they cope with child care and lectures. Commenting further on the lack of support from husbands a respondent said:

"In any case he was not in support of the course so I do not expect any support from him. I just ignore him".

In order to cope with the demands of support for childcare, 78.0 percent of respondents skipped face-to-face meetings to take care of their babies. Furthermore as coping strategies for the financial challenges student mothers face, 78.0 percent of respondents accessed loans from banks, credit unions, and SSNIT, 36.6 percent of respondents arranged for free transport from colleagues, 24.4 percent of respondents minimized attendance and expenses on social gatherings whiles 17.1 percent of respondents relied on husbands and other relatives to help pay fees. This is also in line with Najjuma and Kyarugah (2006) who in their study, found out that, some women either take their children with them, use paid domestic workers, leave children with neighbours, relatives, old siblings or take them to a day care centre as coping strategies for the struggles they go through.

\section{Conclusion}

Motherhood is a sophisticated and a wonderful adventure. This major hurdle becomes more sophisticated when mothers add demands of the global changing roles, such as working outside the home, furthering of education to their many traditional family responsibilities. From the findings of the study it is concluded that the role conflict experienced by student mothers affects their performance 
both at home and in their academic pursuit. The struggles they go through include inability to attend face-face lectures regularly, and inadequate preparation for exams. They are as well unable to perform their childcare functions adequately. Even though they adopt numerous strategies including hiring of house helps, baby sitters, assistance from family members and even stopping some domestic chores in order to cope with the challenges, it is clear that management of CoDE-UCC must provide the Oyoko study center with some services and facilities like counselling, rest rooms and child care centres while the family must be ready to assist student mothers to cope in order to avoid stress.

\section{Conflicts of Interest}

The authors declare no conflicts of interest regarding the publication of this paper.

\section{References}

Adofo, S. (2013). Challenges and Coping Strategies of Student Nursing Mothers in Tertiary Institutions in the Greater Accra Region of Ghana. Unpublished Thesis, Legon: University of Ghana.

Adusah-Karikari, A. (2008). Experiences of Women in Higher Education. A Study of Women Faculty and Administrators in selected Public Universities in Ghana. Ph.D. Dissertation.

Asiedu-Akrofi, K. (1978). School Administration in Modern Africa. Tema: Ghana Publishing Corporation.

Beeler, S. (2016). Undergraduate Single Mothers' Experiences in Postsecondary Education. New Directions for Higher Education, 2016, 69-80. https://doi.org/10.1002/he.20210

Bruening, M., Argo, K., Payne-Sturges, D., \& Laska, M. N. (2017). The Struggle Is Real: A Systematic Review of Food Insecurity on Postsecondary Education Campuses. Journal of the Academy of Nutrition and Dietetics, 117, 1767-1791. https://doi.org/10.1016/j.jand.2017.05.022

Caplan, P. J. (1993). Lifting a Ton of Fathers. A Woman's Guide for Survival in the Academic World. Toronto: University of Toronto Press.

Creswell, J. W. (2014). Research Design: Qualitative, Quantitative and Mixed Methods Approaches (4th ed.). Thousand Oaks, CA: Sage.

Dankyi, J. K., \& Dankyi, L. A. (2015). Perceived Effects of University of Cape Coast Distance Education on Teachers' Performance in the Basic Schools of Kwahu West Municipality. International Journal of Research in Social Sciences, 6, 1-8.

Dolphyne, F. A. C. (1991). The Emancipation of Women: An African Perspective. Accra: University Press.

Edwards, L. N., Hasebe, T., \& Sakai, T. (2019). Education and Marriage Decisions of Japanese Women and the Role of the Equal Employment Opportunity Act. Journal of Human Capital, 13, 260-292. https://doi.org/10.1086/702924

Egenti, M. N., \& Omoruyi, F. E. O. (2011). Challenges of Women Participation in Continuing Higher Education Programme: Implications for Adult Women Counselling and Education. Edo Journal of Counselling, 4, 131-143.

Erickson, E. H. (1982). The Life Cycle Completed. New York: W. W. 
Eyster, L., Callan, T., \& Adams, G. (2014). Balancing School, Work, and Family: Low-Income Parents' Participation in Education and Training. Washington DC: Urban Institute.

http://www.Urban.org/research/publication/balancing-school-work-and-family-low-in come-parents-participation-education-and-training

Goode, W. (1960). Theory of Role Strain. American Sociological Review, 25, 483-496. https://doi.org/10.2307/2092933

Hossain, M., Niaz Asadullah, M., \& Kambhampati, U. (2019). Empowerment and Life Satisfaction: Evidence from Bangladesh. World Development, 122, 170-183. https://doi.org/10.1016/j.worlddev.2019.05.013

Jekayinfa, A. A. (2009). Teaching the Informal Education Skills as Catalyst for Achieving the Millennium Development Goal of Eradicating Poverty in Nigeria. Southern African Journal of Educational Foundations, 3.

Liu, Z., Wang, X., Min, Q., \& Li, W. (2019). The Effect of Role Conflict on Self-Disclosure in Social Network Sites: An Integrated Perspective of Boundary Regulation and Dual Process Model. Information Systems Journal, 29, 279-316. https://doi.org/10.1111/isj.12195

Mamhute, R. (2011). The Challenges of Pregnant and Nursing Adult Learners: A Case Study of Morgenter Teachers' College. Stellenbosch: Stellenbosch University.

Mumuni, B. Y. (2000). Factors Influencing Female Enrolment in Educational Institution in Ghana. A Case Study of West Mamprusi District in the Northern Region of Ghana. Unpublished M. Phil. Thesis, Cape Coast: University of Cape Coast.

Najjuma, S. M., \& Kyarugahe, D. T. (2006). Studying and Parenting: Experiences of Student Mothers in Ugandan Universities. Monograph Series, Mtafiti Mwafrika (African Researcher), 17, 1-22. https://doi.org/10.4314/mtafiti.v17i1.38353

Nelson, B., Froehner, M., \& Gault, B. (2013). College Students with Children Are Common and Face Many Challenges in Completing Higher Education. Briefing Paper\# C404, Institute for Women's Policy Research.

Parson, T. (1971). The Present Status of "Structural-Functional" Theory in Sociology. In T. Parsons (Ed.), Social Systems and the Evolution of Action Theory (p. 218). New York: The Free Press.

Smith, S. (2019). Student-Mothers in Community College: A Populous and Overlooked Demographic in Critical Need for Support and Understanding. Doctoral Dissertation, Northern Kentucky University.

Smulyan, L. (2004). Redefining Self and Success: Becoming Teachers and Doctors. Gender and Education, 16, 225-245. https://doi.org/10.1080/09540250310001690591 